\section{Efficacy and safety of tocilizumab in patients with refractory Takayasu arteritis}

We have read with interest the article by Nakaoka and colleagues $^{1}$ on the efficacy and safety of tocilizumab in patients with refractory Takayasu arteritis. The authors have presented a randomised controlled trial in which they suggest a preference for tocilizumab over placebo for time to relapse of Takayasu arteritis, without any new safety concerns. We would like to draw attention to a few points in this regard.

First, Takayasu arteritis and giant cell arteritis share some similarities in terms of their clinical, radiological and histological presentations, representing a spectrum of the same disease. ${ }^{2}$ Tocilizumab, which is used to treat giant cell arteritis, demonstrates an impressive glucocorticoid-sparing effect, ${ }^{3}$ which is important because relapses are common during steroid tapering, and it often necessitates the administration of high cumulative doses of glucocorticoids, which could cause significant toxicity. ${ }^{4}$ Treatment for Takayasu arteritis is still challenging because glucocorticoids are associated with significant adverse effects. Thus, the use of tocilizumab as a glucocorticoid-sparing agent is appealing. In the context that Takayasu arteritis and giant cell arteritis may be different phenotypes of a single disease, the steroid-tapering effect of tocilizumab is expected in the treatment for Takayasu arteritis. However, this study did not examine the effect of tocilizumab on the tapering of glucocorticoid agents in patients with Takayasu arteritis, because the study was designed with mandatory glucocorticoid tapering. ${ }^{1}$

Second, biologic agents are generally used as second-line treatment. Tocilizumab is usually used in patients with large-vessel vasculitis refractory to immunosuppressants, because of its high cost and potential toxicity. Methotrexate (MTX) and mycophenolate mofetil (MMF) are effective means of inducing remission and minimising glucocorticoid therapy and toxicity in Takayasu arteritis. ${ }^{5}$ MTX and MMF lower the risk of relapse and reduce exposure to glucocorticoids; thus, MTX and MMF are therapeutic options in addition to the standard-of-care treatment with glucocorticoids for Takayasu arteritis. MTX and MMF might be particularly useful in treating patients at high risk of developing glucocorticoid-related adverse effects. However, the efficacy and safety of tocilizumab compared with these immunosuppressive drugs in patients with Takayasu arteritis were not investigated.
Currently, there are no data to show the superiority of tocilizumab over immunosuppressants. Further studies are warranted to determine the benefits of tocilizumab in terms of its glucocorticoid-sparing effect, remission and reduction in relapse, compared with MTX or MMF therapy.

\section{Young Ho Lee, ${ }^{1}$ Gwan Gyu Song ${ }^{2}$}

${ }^{1}$ Division of Rheumatology, Korea University Medical Center, Seoul, South Korea ${ }^{2}$ Department of Rheumatology, College of Medicine, Korea University, Seoul, South Korea

Correspondence to Professor Young Ho Lee, Division of Rheumatology, Korea University Medical Center, Seoul 02841, Republic of Korea; lyhcgh@korea.ac.kr

Handling editor Josef S Smolen

Competing interests None declared.

Provenance and peer review Not commissioned; internally peer reviewed.

(c) Article author(s) (or their employer(s) unless otherwise stated in the text of the article) 2019. All rights reserved. No commercial use is permitted unless otherwise expressly granted.

\section{Check for updates}

To cite Lee YH, Song GG. Ann Rheum Dis 2019;78:e9.

Received 13 December 2017

Accepted 16 December 2017

Published Online First 29 December 2017

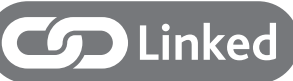

- http://dx.doi.org/10.1136/ annrheumdis-2017-212871

Ann Rheum Dis 2019;78:e9. doi:10.1136/annrheumdis-2017-212838

\section{REFERENCES}

1 Nakaoka Y, Isobe M, Takei S, et al. Efficacy and safety of tocilizumab in patients with refractory takayasu arteritis: results from a randomised, double-blind, placebocontrolled, phase 3 trial in Japan (the TAKT study). Ann Rheum Dis 2018;77:348-54.

2 Polachek A, Pauzner R, Levartovsky D, et al. The fine line between takayasu arteritis and giant cell arteritis. Clin Rheumatol 2015;34:721-7.

3 Stone JH, Tuckwell K, Dimonaco S, et al. Trial of tocilizumab in giant-cell arteritis. N Engl J Med 2017:377:317-28.

4 Proven A, Gabriel SE, Orces C, et al. Glucocorticoid therapy in giant cell arteritis: duration and adverse outcomes. Arthritis Rheum 2003:49:703-8.

5 Hoffman GS, Leavitt RY, Kerr GS, et al. Treatment of glucocorticoid-resistant or relapsing Takayasu arteritis with methotrexate. Arthritis Rheum 1994;37:578-82. 